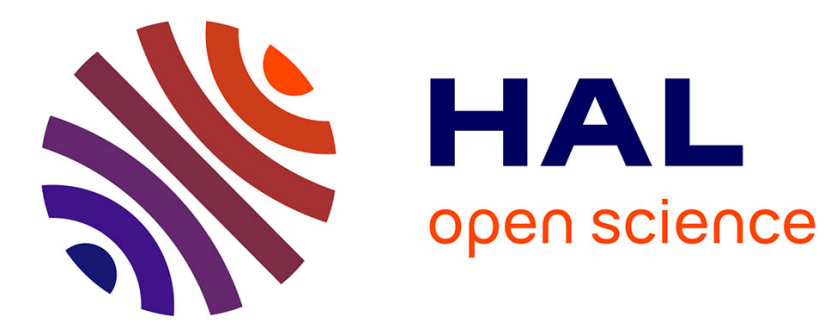

\title{
High Temperature Intermetallic Compounds Ni3Al
}

\author{
M. Kursa, L. Hypeská, J. Drápala, T. Kárník, M. Losertová
}

\section{To cite this version:}

M. Kursa, L. Hypeská, J. Drápala, T. Kárník, M. Losertová. High Temperature Intermetallic Compounds Ni3Al. Journal de Physique IV Proceedings, 1995, 05 (C7), pp.C7-123-C7-128. 10.1051/jp4:1995710 . jpa-00254003

\section{HAL Id: jpa-00254003 https://hal.science/jpa-00254003}

Submitted on 1 Jan 1995

HAL is a multi-disciplinary open access archive for the deposit and dissemination of scientific research documents, whether they are published or not. The documents may come from teaching and research institutions in France or abroad, or from public or private research centers.
L'archive ouverte pluridisciplinaire HAL, est destinée au dépôt et à la diffusion de documents scientifiques de niveau recherche, publiés ou non, émanant des établissements d'enseignement et de recherche français ou étrangers, des laboratoires publics ou privés. 


\title{
High Temperature Intermetallic Compounds $\mathrm{Ni3} \mathrm{Al}$
}

\author{
M. Kursa, L. Hypeská, J. Drápala, T. Kárník and M. Losertová \\ VSB, Technical University Ostrava, av. 17. listopadu, 70833 Ostrava-Poruba, Czech Republic
}

\begin{abstract}
The paper describes the preparation of Ni3 Al intermetallic compounds, and investigations of their structures in the as-cast, remelted, and annealed states. The materials were produced by three techniques : in a high frequency vacuum furnace, by zonal remelting in an electron beam furnace, and by remelting with unidirectional solidification. Those melted in an h. f. vacuum furnace and poured into graphite moulds had well developed dendritic structures, a $\mathrm{Ni3Al}\left(\gamma^{4}\right)$ phase, with interdendritic spaces formed by Ni5Al3 $+\gamma^{*}$. Many specimens contained shrinkage cavities. Unidirectional solidification allowed casting defects to be eliminated and the grain size to be controlled in dependence on the solidification rate. Rates from 650 to $60 \mathrm{~mm}$ per hour were tried to examine their effects on the grain size, homogeneity, and structure. The authors further investigated the influence of $\mathrm{B}$ and $\mathrm{Zr}$ additions on the solidification process and formation of the structure of $\mathrm{Ni} 3 \mathrm{Al}$. Annealing, in an argon atmosphere at $1100^{\circ} \mathrm{C}$ for various durations, was tried out for homogenizing the as-cast structures.
\end{abstract}

\section{INTRODUCTION}

Ordered intermetallic Ni3Al compounds are known to be promising structural materials for service at elevated temperatures [1]. Most authors $[1,2,3,4]$ state that in their polycrystalline form, they are brittle at room temperature and fracture in the intercrystalline mode. This is due to their intrinsically weak grain boundaries, caused by the structural state of the material, but these can be influenced for instance by the solidification procedure [5], by boron and other additions $[3,4,5,6,7,8]$, or by the outer environment [9]. The countermeasure which has been studied most frequently is a boron addition, which can significantly enhance both ductility and yield strength [7]. Boron, however, may segregate [2] and thereby affect the structure and geometry of the grain boundaries, grain size and growth, and the cohesive strength of the grains [3,4] ; it may also modify the Ni3Al alloy by dissolving in it, thereby increasing the concentration of interstitials and macroscopically strengthening the matrix by increasing the resistance of the matrix and of its defects to dislocation glide [7].

The research reported in this paper was devoted to a stoichiometric Ni3 Al alloy with boron or zirconium additions. The pure stoichiometric Ni3Al was produced by three different techniques :

- in a high frequency vacuum furnace,

- by unidirectional solidification, or

- by zone melting in an electron beam furnace.

This paper deals only with the effects of various preparation techniques, environments and additions on the grain size and hardness of the alloy. 


\section{EXPERIMENTAL PROCEDURE}

All the specimens of pure stoichiometric Ni3Al based alloy (denoted "A" below )were prepared in a high frequency vacuum furnace at 11 to $15 \mathrm{~kW}$; these specimens, of $0.5 \mathrm{~kg}$ each, were made of $99.99 \%$ pure nickel (obtained by refining electrolytic nickel in a plasma furnace) and $99.99 \%$ pure aluminium (obtained by three-stage electrolysis with normal $\mathrm{Fe}$ and $\mathrm{Si}$ contents). Where the effects of additions were investigated, boron was added either in powder form (further denoted $A+0.1$ at. \% B) or else in the form of Ni3B alloy (denoted A+1. 0 at. \% B). Zirconium was added either in metallic form (denoted A+1. 0 at. \% $\mathrm{Zr}$ ) or else as ZrB2 alloy (denoted A+1. 0 wt. \% ZrB2).

Vacuum melting with subsequent homogenization of the melt, and pouring in an argon atmosphere into graphite moulds, yielded specimens or test coupons, for unidirectional solidification or electron beam zone melting, which were $12 \mathrm{~mm}$ in diameter and $120 \mathrm{~mm}$ long. Some specimens were given an optimum heat treatment of 10 hours at $1100^{\circ} \mathrm{C}$ followed by cooling in still air, to produce a single-phase microstructure; these specimens are further marked A+TT [10]. Some of the test coupons were subjected to unidirectional solidification at a displacement rate of either 63 or $642 \mathrm{~mm} / \mathrm{hour}$, further denoted A+US63 and A+US642 respectively, with a temperature gradient of about 45 to $60 \mathrm{~K} / \mathrm{cm}$. Finally, the remaining test coupons were zonally remelted in an electron beam furnace by the floating zone method, at a displacement rate of $180 \mathrm{~mm} /$ hour and a zone width of 12 to $15 \mathrm{~mm}$; these are further marked A+ZE.

\section{RESULTS AND DISCUSSION}

Table I summarizes the findings of optical microscopy and of Vickers hardness HV(10) measurements on specimens produced by the various techniques listed above. Only unidirectional solidification at the slower rate $(\mathrm{A}+\mathrm{US} 63$ in the Table) with cellular growth $(\mathrm{A}+\mathrm{ZE})$ resulted in the solidification of an almost single-phase $\mathrm{Ni} 3 \mathrm{Al}$ structure.

In all other cases the structures also contained some NiAl, as observed earlier in dendritic structures [11], and as reported previously e. g. by Toshio Mawari and Toshiyuki Hirano [5]. These two authors claimed that a simple Ni3Al phase arises only by the unidirectional solidification, with a floating zone and slow cellular growth, of stoichiometric Ni3Al, which yields a columnar structure. In our work these conditions were met by $A+Z E$ (see Fig. 3 and Table I), except for the growth rate. That explains why we then gained a duplex rather than a single-phase structure. A slow growth of columnar crystals can thus be considered an essential condition for the formation of a single-phase structure : rapid growth causes dendritic solidification, and cooling then produces a duplex structure of $\mathrm{Ni3} \mathrm{Al}$ and $\mathrm{NiAl}$, as is visible e. g. in Fig. 1.

Fig. 4 presents the results of PDAS versus growth rate measurements [6], along with plots of theoretical values obtained by the Hunt model and by the Kurz and Fisher model ; also plotted are the findings of our present work, which will be seen to lie within the range of the model-based values, as do the previuosly quoted results [6]. The results attained in prior work [5] by unidirectional solidification using a floating zone method, which yielded a columnar-grained structure of single-phase $\mathrm{Ni3 \textrm {Al }}$, are significant in that brittleness was supressed and elongation markedly increased (to as much as $70 \%$ ) without any additions, without a neutral environment, and without necking. Scanning electron microscopy of the fracture surfaces revealed only ductile transgranular failure. In two-phase structures, cracks initiated at the $\mathrm{Ni} 3 \mathrm{Al} / \mathrm{NiAl}$ phase boundaries and then propagated to the adjacent $\mathrm{Ni3Al}$ matrix. That is the explanation advanced before [5] for the fact that two-phase structures displayed elongation values negligible in comparison with those found in single-phase structures.

A simple equiaxe $\mathrm{Ni} 3 \mathrm{Al}$ structure was also gained by annealing a dendritic two-phase structure for 10 hours at $1100^{\circ} \mathrm{C}$, but its grain size, of $300 \mu \mathrm{m}$ on average, was larger than the originally ascertained PDAS of $200 \mu \mathrm{m}$. This is evident from a comparison of Figs. 1 and 2. 
Table I : Results of metallographic observations and hardness measurements on specimens produced by various techniques

* In dendritic microstructures, "grain size" means the primary dendrite arm spacing, PDAS

\begin{tabular}{|c|c|c|c|c|}
\hline Technique & $\begin{array}{l}\text { Grain* } \\
\text { size }[\mu \mathrm{m}]\end{array}$ & $\overline{\mathrm{HV}(10)}$ & Phase & Main microstructure \\
\hline A & 200 & 191 & $\begin{array}{c}\text { Two phase } \\
\text { Ni3Al+(NiAl) }\end{array}$ & Dendritic, Fig. la \\
\hline $\begin{array}{c}\mathrm{A}+\mathrm{TT} \\
\mathrm{A}+\mathrm{US} 63\end{array}$ & $\begin{array}{l}300 \\
390\end{array}$ & $\begin{array}{l}180 \\
170\end{array}$ & $\begin{array}{l}\text { Single } \mathrm{Ni3Al} \\
\text { Near single }\end{array}$ & $\begin{array}{c}\text { Equiaxe, Fig. } 2 \\
\text { Cellular+dendritic growth }\end{array}$ \\
\hline & 200 & 175 & $\begin{array}{c}\text { Two phase } \\
\text { Ni3Al+(NiAl) }\end{array}$ & Dendritic+cellular growth \\
\hline $\mathrm{A}+\mathrm{ZE}$ & 2200 & 155 & $\begin{array}{l}\text { Two phases } \\
\text { Ni3Al+NiAl }\end{array}$ & $\begin{array}{l}\text { Cellular growth, } \\
\text { Fig. } 3 \text { b } \\
\text { Columnar grained }\end{array}$ \\
\hline $\bar{A}+0,1$ at. $\% \mathrm{~B}$ & 300 & 177 & Two phases & Dendritic \\
\hline $\mathrm{A}+1,0$ at. $\% \mathrm{~B}$ & 210 & 250 & Two phases & Dendritic, Fig. 1b \\
\hline $\mathrm{A}+1,0$ at. $\% \mathrm{Zr}$ & 80 & 232 & Two phases & Dendritic, Fig. 1c \\
\hline $\mathrm{A}+1,0 \mathrm{wgt}$. & 140 & 310 & Two phases & Dendritic \\
\hline $\begin{array}{c}\mathrm{A}+0,1 \text { at. } \% \mathrm{~B}+ \\
+1,0 \text { at. } \% \mathrm{Zr}\end{array}$ & 0 & 252 & $\begin{array}{l}\text { Ni3Al+(NiAl) } \\
\text { Two phases } \\
\text { Ni3Al+(NiAl) }\end{array}$ & Dendritic \\
\hline
\end{tabular}

Knowledge of the way grain size varies with the parameters of solidification and of the subsequent annealing processes is vital, in view of the fact that the strength properties of metallic systems are strongly dependent on the grain size. The best known expression for this relationship is the Hall-Petch equation

$$
\sigma_{\mathrm{L}}=\sigma_{0}+\mathrm{k}_{\mathrm{y}} \mathrm{d}^{-1 / 2}
$$

where $\sigma \mathrm{L}$ is the fracture stress, and $\sigma 0$ and ky are constants representing friction stress in the lattice and expressing the contribution made by the grain boundaries towards the fracture stress. Fig. 5a shows the dependences of hardness on grain size in specimens produced by the first five of the techniques listed in Table $\mathrm{I}$, and Fig. $5 \mathrm{~b}$ is a similar chart for an exponent value of 0 . 8. This greater exponent value was established by Schulson et al. [7] for calculating the yield points of stoichiometric Ni3Al-based alloys. The diagrams indicate a close relationship : on both of them hardness declines as the grain size increases, but they afford no definite clue as to which of the exponents, 0.5 or 0.8 , is closer to reality.

The effects of boron and zirconium additions on the microstructure are clearly visible in Fig. 1, and their influence on the grain size is set out in Table $\mathrm{I}$. Zirconium profoundly refined the PDAS and increased the hardness ; boron had less effect on the hardness level. A detailed investigation of the way these additions affect hardness will, however, have to take into account not only the PDAS size, but also the duplex phases formed, especially their amounts and their influence in the solid solution; this will call for further research. 
a)

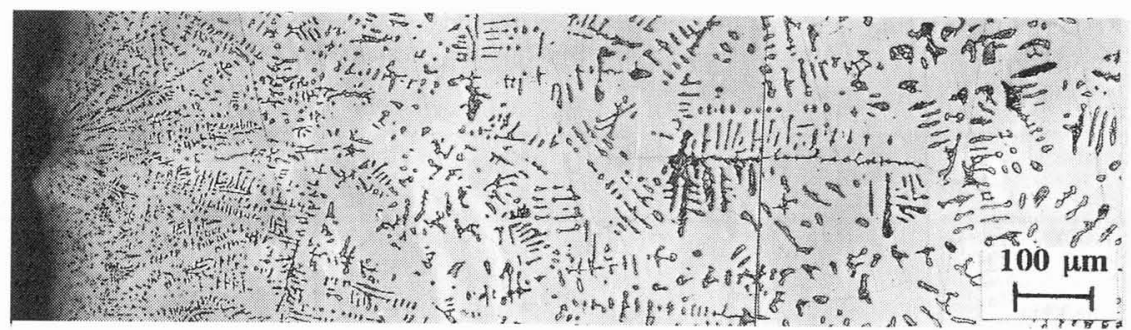

b)

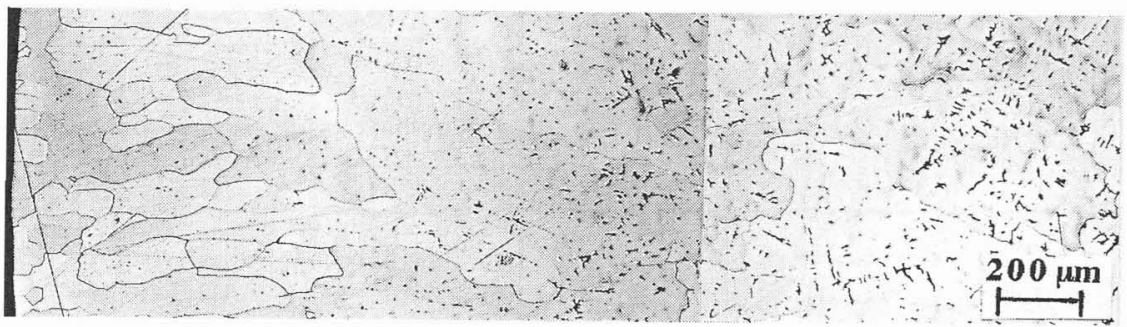

c)

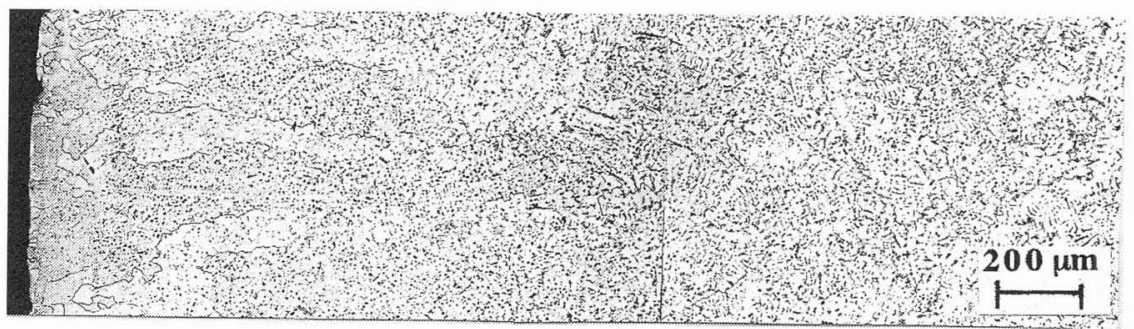

Fig. 1 : Effect of 1.0 at. \% of boron or zirconium in specimens A : a) with no additions ; b) with 1.0 at. $\% \mathrm{~B}$; c) with 1.0 at. $\% \mathrm{Zr}$ (perpendicular section).

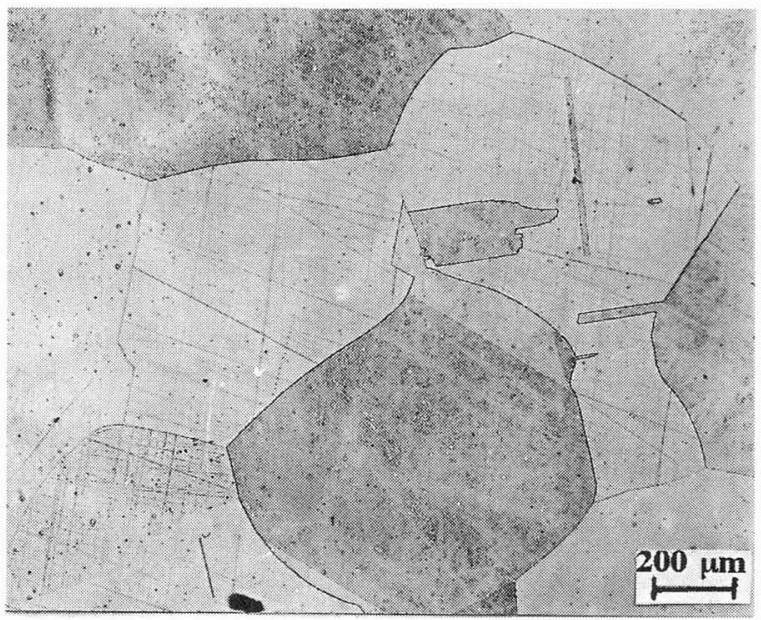

Fig. 2 : Equiaxe microstructure after 10 hours of annealing at $1100^{\circ} \mathrm{C}(\mathrm{x} 100)$ 


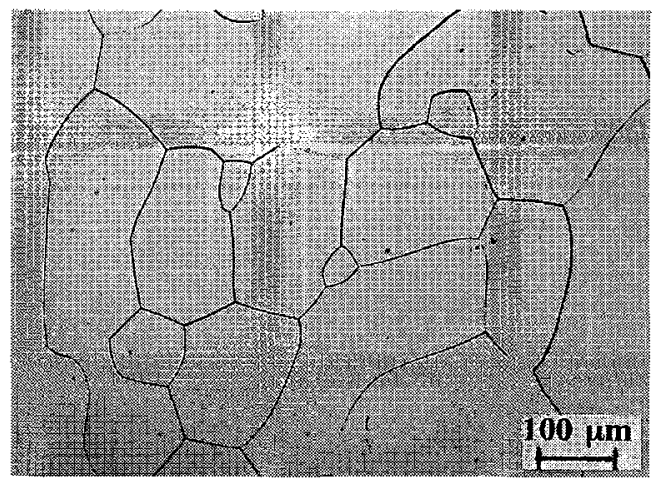

a) After A+US63 treatment treatment (perpendicular to growth direction) (x 50)

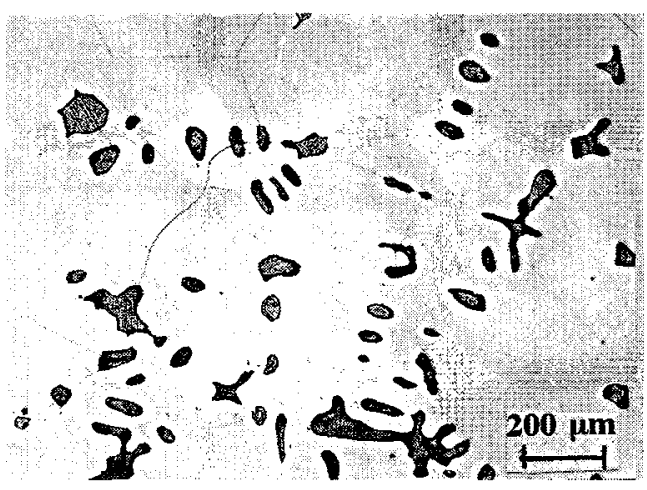

b) After A+ZE

(perpendicular to growth direction) (x 100)

Fig. 3 : Microstructure Ni3Al

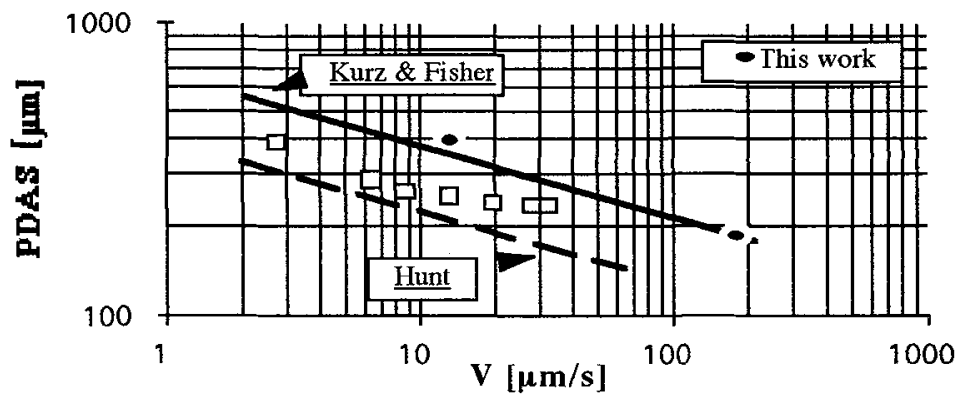

Fig. 4 : Primary dendrite arm spacing as a function of growth rate (temperature gradient of $54.4 \mathrm{~K} / \mathrm{cm}$ ), according to [6].

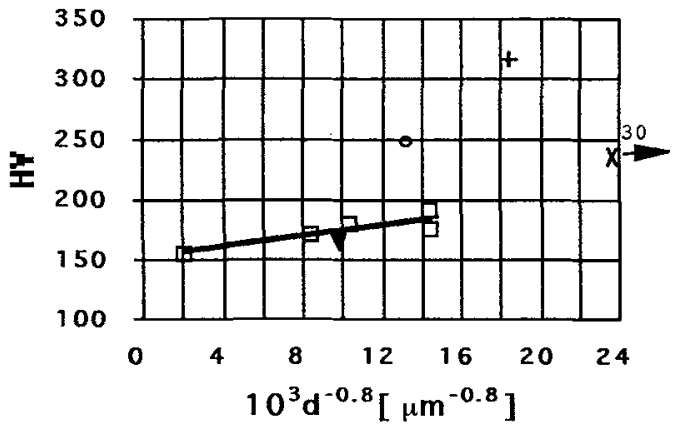

$\mathrm{Ni}_{3} \mathrm{Al}$

$+1.0 \mathrm{wt} . \% \mathrm{ZrB}_{2}$
( without additional elements - 1.0 at. \% B

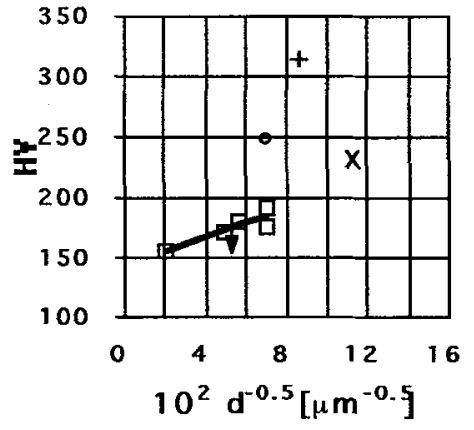

$\times 1.0$ at. $\% \mathrm{Zr}$

v 0.1 at.\% B

Fig. 5 : Relationships between hardness and grain size, $\mathrm{d}: \mathrm{HV}=\mathrm{HV}_{0}+\mathrm{k}_{\mathrm{y}} \cdot \mathrm{d}^{-\mathrm{n}}$ a) $n=1 / 2 ; b) n=0.8 ;$ in dendritic structures $d=$ PDAS. 


\section{CONCLUSIONS}

1. For pure stoichiometric Ni3 Al, we can determine the set of solidification parameters which produce a virtually single-phase $\mathrm{Ni}_{3} \mathrm{Al}$ alloy with a columnar-grained structure.

2. Stoichiometric $\mathrm{Ni} 3 \mathrm{Al}$ can be converted from a duplex to a single-phase equiaxe structure by not less than 10 hours of annealing at $1100^{\circ} \mathrm{C}[10]$.

3. Boron additions increased the hardness, zirconium additions pronouncedly refined the microstructure.

4. The grain size of Ni3Al-based alloys depends on the solidification and annealing parameters ; the hardness of these alloys declines as the grain size increases.

\section{References}

[1]Stoloff, N. S., Internationals Materials Reviews 1989, Vol. 39, pp. 154-183.

[2] Lin, T. L., Da Chen and Hui Lin., Acta metall. mater. 1991, Vol. 39, No. 4, pp. 523-528.

[3] Kerans, R. J., Hirth, J. P. and Clark, W. A. T., Acta metall. mater. 1995, Vol. 43, No. 1, pp. 277-285.

[4] Âwiatnicki, W. A. and Grabski, M. W. Acta metall. 1989, Vol. 37, No. 5, pp. 1307-1311.

[5] Mawari Toshio and Hirano Toshiyuki, Intermetallic 1995, No. 3, pp. 23-33.

[6] Kim, H. K., Earthman, J. C. and Lavernia, E. J., Acta metall. mater. 1992, Vol. 40, No. 4, pp. 637-647.

[7] Schulson, E. M., Su, Y., Minroe, P. R., Guha, S. and Baker I., Acta metall. mater. 1991, Vol. 39, No. 12, pp. 2971-2975.

[8] Webb, G. and Antolovich, S. D., Metallurgical and Materials Transactions A 1994, Vol. 25 A, pp. 24692476.

[9] Yang, L. and McLellan, R. B., Acta metall. mater. 1994, Vol. 42, No. 12, pp. 3993-3996.

[10] Kursa, M., Losertová, M., Hyspecká, L. and Svoboda M., Preparation, Structure and Properties of Intermetallic Compounds on the Base of Nickel, METAL "94", Ostrava, II, pp. 64-78.

[11] Hyspecká, L., Skleniãka, V., Kursa, M., Schindler, I., Losertová, M. and Drápala, J., Research of Plastic and Service Properties of Intermetallic Compounds, VSB-TU Ostrava, 1993, 84 pp. 